Джамалов К.Э. Учет национально-ориентированного компонента при обучении русскому языку учащихся-дагестанцев

УДК 808.2-06(075.8)

DOI: $10.21779 / 2542-0313-2018-33-1-79-83$

\title{
К.Э. Дюсамалов
}

\section{Учет национально-ориентированного компонента при обучении русскому языку учащихся-дагестанцев}

Дагестанский государственный университет; 367001, Республика Дагестан, г. Махачкала, ул. М. Гаджиева, 43a; filfak37a@mail.ru

Статья посвящена учету национально-ориентированного компонента при обучении русскому языку на всех языковых уровнях: фонетическом, грамматическом (морфологическом и синтаксическом) и лексическом, так как в условиях двуязычия неизбежны интерференционные ошибки в русской речи билингвов. Учет национально-регионального компонента будет способствовать сознательному и успешному изучению русского языка, формированию нормированной русской речи.

Ключевые слова: начионально-региональный компонент, проблема двуязычия, многозначность слова, интерференционные ошибки, полиэтническая среда, уровни языка, формирование речи на втором языке.

В процессе обучения русскому языку учащихся национальной школы наиболее важным является учет особенностей родного языка билингвов. Игнорирование влияния родного языка ведет к возникновению так называемых типичных ошибок. Причинами подобных ошибок являются различия не только в фонетической системе, но и в грамматическом строе русского и дагестанских языков. Для успешного обучения русскому языку учащихся-дагестанцев учителю необходимо знать особенности родного языка, заранее предвидеть трудности, связанные с расхождениями в грамматическом строе русского и родного языка учащихся.

В Республике Дагестан, где отсутствует русскоязычная среда, школа является основным центром формирования национально-русского двуязычия. Учителя русского языка давно нуждаются в научно обоснованной методике преподавания русского языка с учетом регионального и федерального компонентов и особенностей национальной школы.

«Методика обучения русскому языку в полиэтнических классах должна предполагать обучение нерусских учащихся национальной культуре русского народа, ее специфике, которая отличается от родной культуры. Правилам речевого поведения на уроках русского языка необходимо обучать с учетом национальных особенностей речевого поведения нерусских этносов» [2, с. 32].

Сегодня практическое овладение русским языком занимает особое место в коммуникативной компетенции. Значительно возросли требования к обучению русскому языку, так как выпускники средней общеобразовательной школы должны сдать в обязательном порядке единый государственный экзамен по русскому языку.

Формирование национально-русского двуязычия относится к числу важнейших социолингвистических и педагогических проблем, так как основная часть затрагивае- 
Джамалов К.Э. Учет национально-ориентированного компонента при обучении русскому языку учащихся-дагестанцев

мых современным человечеством материальных ресурсов, научных исследований, человеческой энергии и времени для изучения и исследования языков связана с формированием двуязычия, разработкой в этих целях методического аспекта обучения второму языку.

Учет особенностей родного языка в процессе преподавания русского языка позволит заранее предупредить и преодолеть возможные интерференционные ошибки в русской речи учащихся-дагестанцев, обусловленные влиянием родного. К сожалению, сегодня изучение русского языка в средних и старших классах осуществляется по единым федеральным программам и учебникам без учета особенностей родного языка [10, c. 17].

При обучении русскому языку следует учесть сходства различия и в русском и родном языках на лексическом, фонетико-фонологическом, словообразовательном и грамматическом (морфологическом и синтаксическом) уровнях. При этом следует продумать, обосновать и обеспечить повторяемость трудных тем по орфографии и пунктуации для повышения грамотности учащихся. Такая продуманная работа должна способствовать формированию нормированной русской речи и преодолению интерференции в речи билингвов.

В школах с национальным (дагестанским) составом учащихся в процессе изучения русского языка необходимо учесть различнгые особенности родного языка.

\section{На фонетическом уровне:}

а) отсутствие во многих дагестанских языках (кроме аварского и цахурского) гласного $O$ приводит к замене его гласным $У$ или $A$ : говорю [гавару], договор [дагавур];

б) отсутствие в дагестанских языках (кроме рутульского и цахурского) гласного Ы приводит к замене его гласным И: высокий [високий], цыплята [циплйата], красный [красний];

в) наличие в дагестанских языках фарингализованных гласных $A 1, y 1, O 1$ приводит к произношению гласных $A, V, O$, наподобие соответствующих фарингализованных: пятый [пА1тый], мёд [мО1д];

г) мягкое (в лучшем случае полумягкое) произношение шипящих Ж, [жил, широкий, цирк] вместо [жыл, шырокий, цырк];

д) отсутствие в дагестанских языках долгих мягких шипящих ЖЖ и Щ приводит к их замене полумягкими шипящими Ж и Ш: дрожж [дроЖи], щуенок [Шинок], щуи [Ши];

е) отсутствие в дагестанских языках дифференциации согласных по признаку мягкости и твердости приводит к замене мягких согласных твердыми или в лучшем случае - полумягкими: больной [балнуй], фонарь [фанар];

ж) произношение глухих согласных $\Pi, T, K, Ц$ с придыханием: птица [пытица], круглый [куруглый], тряпка [тыряпка];

3) вставка слогообразующего гласного при произношении слов со стечением согласных: спички [испички], стакан [истакан] и т. д. [4, с. 127].

\section{На морфологическом уровне:}

a) отсутствие в дагестанских языках грамматической категории рода приводит к нарушению согласования определения с определяемым словом; особенно трудно учащимся определить род существительных, оканчивающихся на Ь, типа: бандероль, мозоль, шампунь, шинель, рояль и т. д.;

б) наличие эргативного падежа во всех дагестанских языках (при переходных глаголах подлежащее выражается эргативным падежом, а при непереходных глаголах именительным падежом);

80 Вестник Дагестанского государственного университета.

Серия 2. Гуманитарные науки. 2018. Том 33. Вып. 1 
Джамалов К.Э. Учет национально-ориентированного компонента при обучении русскому языку учащихся-дагестанцев

в) отсутствие предлогов в родном языке учащихся и отсюда много ошибок в употреблении предлогов в русской речи учащихся: иду школу, живу в Кавказе, слез из дерева и т. д.;

г) отсутствие видовой дифференциации приводит к ошибкам типа: буду прочитать, начал поработать;

д) отсутствие возвратных глаголов.

На синтаксическом уровне:

а) ошибки согласования в роде: У меня есть бельй рубашка;

б) ошибки согласования в числе: Мы давно не покупаем новый газет;

в) ошибки согласования в падеже: Наше село расположено на высокой холму;

г) ошибки в предложном именном и глагольном управлении: Я окончил школу 2015 год;

д) ошибки в беспредложном именном и глагольном управлении: B нашем классе учатся тринадиать мальчики и десять девочки;

е) ошибки, связанные с несовпадением порядка слов в словосочетании и предложении в русском и родном языках учащихся и различиями в структуре простого и сложного предложения: Мой друг на вечере Расула Гамзатова стихи читал и т. д.

На лексическом уровне. Национально-региональный компонент содержания лексики понимается нами как отобранный в учебных целях лексический материал, специфичный для той или иной местности и отражающий ее особенности, призванный обеспечить активное и полноценное включение учащихся в окружающую социальную и культурную среду.

Лексико-семантические ошибки обусловлены тем, что понятия, характерные для русского и дагестанских языков, по-разному отражают действительность. Это означает, что даже эквивалентные слова русского и дагестанских языков в большинстве не являются однозначными и полностью не совпадают. Лексико-семантический вариант слова, усвоенный билингвами первоначально, доминирует в его сознании, а вторичные значения слова не всегда воспроизводят правильно. Например, не различают слова невеста и невестка, сноха, так как в родном языке учащихся одно слово (в лезг. сос, в рут. сус) совмещает в себе значение названных трех русских слов [5, с. 27].

Основной причиной, порождающей лексико-семантическую интерференцию, следует считать стремление учащихся передать значение русских слов по аналоги и с нормами словоупотребления в родном языке. Большинство лексических ошибок связано с неправильной передачей отдельных значений многозначного русского слова. Многозначность слова, характерная для многих языков, в разных языках реализуется поразному. Причиной возникновения интерференции в данном случае является неодинаковый семантический объем слов родного изучаемого языка. Например, глаголы ехать и ездить в родном языке билингвов выражают действие, происходящее к средствам, с помощью которых совершается данный процесс. Поэтому часто слышим в русской речи учащихся-дагестанцев выражения типа Отеи пошел на автобусе город - вместо Отеи поехал на автобусе в город; Брат пришел мотоциклом поздно ночью - вместо Брат приехал на моточикле поздно ночью.

Следует отметить, что национально-региональный компонент содержания образования достаточно широкий и многоаспектный. Он включает в себя не только родной язык и родную литературу, но и историю народа, его культуру, традиции, особенности речевого общения и т. д.

Современные образовательные технологии в национальной школе требуют, чтобы методика опиралась на научно-лингвистические основы формирования речи на втором 
языке. Это значит, что необходимо квалифицированно использовать результаты сопоставительного исследования языков (русского и родного) в учебных целях, психологию восприятия речи на неродном языке, принцип практической направленности обучения русскому языку как неродному, принцип связи теории с практикой.

Таким образом, в процессе изучения русского языка необходимо учесть национально-региональный компонент, все трудные языковые различия на языковом, фонетико-фонологическом, лексическом, словообразовательном и грамматическом уровнях языка, обусловленные влиянием родного языка. Такая продуманная работа будет способствовать сознательному и успешному усвоению русского языка и литературы в дагестанской национальной школе.

\section{Литература}

1. Баранов М.Г. Ипполитова Н.А., Ладыженская Т.А., Панов М.Р. Методика преподавания русского языка. - М., 2000.

2. Бжиева М.А. Особенности обучения русскому языку в классе с полиэтническим составом // Молодой ученый. - 2017. - № 31. - С. 32.

3. Буржунов Г.Г. Методика преподавания русского языка в дагестанской национальной школе. - Махачкала, 2008.

4. Джамалов K.Э. Учет регионального компонента при обучении фонетике русского языка учащихся-дагестанцев // Материалы Всероссийской научно-практической конференции «Взаимодействие языков и культур при изучении русского языка как неродного: опыт и перспективы, 8 ноября, 2017 г. - Махачкала, 2017. - С. 127.

5. Джамалов К.Э. Лексико-семантическая интерференция в русской речи двуязычных дагестанцев. - Махачкала, 2008.

6. Кожевникова М.И. Национально-ориентированная модель обучения иностранных граждан в российских вузах: монография. - М.: Наука, 2016. - 160 с.

7. Крючкова Л.С. Падежная и предложно-падежная система русского языка: функционально-семантический аспект: монография. - М.: Наука, 2017. - 136 с.

8. Кудинова Г.Ф. Технология преподавания русского языка в мультикультурном контексте: методические рекомендации. - Уфа, 2016. - С. 26.

9. Методика русского языка в дагестанской национальной школе / под ред. Магомедова Г.И. - Махачкала, 2004.

10. Шурпаева М.И. Социолингвистические и методические предпосылки обучения русскому языку как неродному в условиях формирования раннего двуязычия // Электронный научный журнал «Язык и текст». - 2016. - Т. 3, № 1.

11. Юсупова 3.Ф. Учет особенностей родного языка при обучении русскому: учебно-методическое пособие. - Казань: Казан. ун-т, 2013.

Поступила в редакциию 7 января 2018 г. 
UDC 808.2-06(075.8)

DOI: $10.21779 / 2542-0313-2018-33-1-79-83$

\section{Nationally-oriented component in teaching Dagestan students the Russian language}

\section{K.E. Dzhamalov}

Dagestan State University; Russia, 367001, Makhachkala, M. Gadzhiev st., 43a; filfak37a@mail.ru

The article is devoted to the consideration of the national-oriented component in teaching the Russian language at all language levels: phonetic, grammatical (morphological and syntactic) and lexical, as in the conditions of bilingualism interference errors in the Russian bilingual speech are inevitable. Consideration of the national and regional component will contribute to the conscious and successful study of the Russian language, the development of skills and normalized Russian speech.

Keywords: national-regional component, the problem of bilingualism, the ambiguity of words, an interference error, multi-ethnic environment, levels of language, formation of speech in a second language, etc.

Received 7 January, 2018 